\title{
Hubungan Kemampuan Pemecahan Masalah Matematis dengan Kemampuan Komunikasi Matematik Siswa
}

\author{
Hestu Tansil Laia ${ }^{1}$, Darmawan Harefa ${ }^{1},{ }^{2}$ \\ STKIP Nias Selatan \\ e-mail:hestutansil@gmail.com, harefadarmawan@gmail.com
}

Received: 12 Januari 2021; Revised: 26 Februari 2021; Accepted: 28 April 2021

DOI: http://dx.doi.org/10.37905/aksara.7.2.463-474.2021

\begin{abstract}
Abstrak
Penelitian ini bertujuan: untuk mengetahui apakah ada hubungan kemampuan pemecahan masalah matematis siswa dengan kemampuan komunikasi matematis siswa. Jenis penelitian yang digunakan yaitu penelitian kuantitatif dengan metode korelasional. Populasi dalam penelitian ini adalah kelas VII dengan jumlah 67 orang siswa. Pengambilan sampel dilakukan dengan teknik total sampling yang artinya semua populasi dijadikan sebagai sampel. Instrumen penelitian yang digunakan berupa soal tes kemampuan pemecahan masalah matematis dan kemampuan komunikasi matematis. Analisis data menggunakan uji prasyarat model regresi linier, uji koefisien korelasi rumus Product Moment, uji t koefisien korelasi, dan koefisien determinasi. Hasil penelitian ini menunjukkan bahwa terdapat hubungan yang positif dan signifikan antara kemampuan pemecahan masalah matematis dengan kemampuan komunikasi matematis siswa, dimana $r=0,40$ dan $t_{\text {hitung }}=3,5043>t_{\text {tabel }}=1,9971$. Sehinggga dapat disimpulkan bahwa terdapat hubungan yang positif dan signifikan antara kemampuan pemecahan masalah matematis dengan kemampuan komunikasi matematis siswa, karena kemampuan komunikasi matematika dapat membantu menghasilkan model matematika yang diperlukan dalam pemecahan masalah baik dalam berbagai ilmu pengetahuan maupun dalam kehidupan sehari-hari.
\end{abstract}

Kata Kunci

Hubungan, Kemampuan Pemecahan Masalah, Komunikasi, Matematis Siswa

\begin{abstract}
This study aims: to see whether there is a relationship between students 'mathematical problem management abilities and students' mathematical communication skills. The type research used is quantitative research with correlational methods. The population in this study was class VII with a total of 67 students. Sampling was carried out by total sampling technique, which means that all populations were sampled. The research instrument used was test of mathematical problem ability and mathematical communication skills. The data analysis used the prerequisite test the linear regression model, the free test of the Product Moment formula, the lack of t test, and the coefficient of determination. The results of this study indicate that there is a positive and significant relationship between mathematical problem skills and students' mathematical communication skills, where $r=0.40$ and $t_{\text {count }}=3.5043>t_{\text {table }}=1.9971$. So it can be ignored that there is a positive and significant relationship between mathematical problem abilities and students' mathematical communication skills, because mathematical communication skills can help produce mathematical models needed in problems both in various sciences and in everyday life.

Keywords

Relationships, Problem Solving Ability, Communication, Student Mathematics
\end{abstract}




\section{Pendahuluan}

Pendidikan pada dasarnya merupakan suatu investasi pembangunan sumber daya manusia yang sangat diperlukan dalam pembangunan sosial dan ekonomi suatu masyarakat dan suatu bangsa. Pendidikan dewasa ini diselenggarakan semakin demokratis, semakin merata dan terbuka bagi setiap orang untuk mengembangkan kapasitas yang ada dalam diri mereka. Seperti yang dikemukakan (Harefa, D., 2020) bahwa "pendidikan merupakan proses membantu orang mengembangkan kapasitas untuk belajar bagaiamana menghubungkan kesulitan mereka dengan teka-teki yang berguna untuk membentuk masalah". Oleh karena itu, pendidikan semakin banyak memerlukan berbagai keahlian profesional dalam sistem manajemennya serta memerlukan berbagai keahlian yang bersifat interdisipliner dalam memecahkan masalah.

Menurut (Slameto, 2010) "Belajar ialah suatu proses usaha yang dilakukan seseorang untuk memperoleh suatu perubahan tingkah laku yang baru secara keseluruhan, sebagai hasil pengalamannya sendiri dalam interaksi dengan lingkungannya". (Harefa, D., Telambanua, 2020) juga mengemukakan bahwa "Belajar adalah proses mental yang terjadi dalam diri seseorang, sehingga menyebabkan munculnya perubahan perilaku". Menurut (Dimyati dan Mudjiono, 2009) "belajar merupakan tindakan dan perilaku siswa yang kompleks". Menurut (Telaumbanua, M., Harefa, 2020) "Belajar dapat didefinisikan sebagai suatu proses dimana suatu organisasi berubah perilakunya sebagai akibat pengalaman"

Untuk mewujudkan harapan tersebut, maka diadakan suatu proses pembelajaran di sekolah. Sekolah merupakan suatu lembaga yang digunakan untuk kegiatan belajar bagi para peserta didik. Melalui proses belajar di sekolah, peserta didik dibekali dengan berbagai ilmu pengetahuan, guna menghadapi tantangan global yang berkembang pesat saat ini. Salah satu ilmu pengetahuan itu ialah matematika.

Ilmu matematika memiliki peranan penting pada era kemajuan ilmu pengetahuan dan teknologi yang ada pada saat ini. Buktinya, kemajuan ilmu pengetahuan dan teknologi juga merupakan bagian kontribusi dari matematika. Matematika adalah suatu alat untuk mengembangkan cara menyelesaikan suatu masalah. Sejalan dengan pendapat (Susanto, 2015) bahwa "matematika merupakan salah satu displin ilmu yang dapat meningkatkan kemampuan berpikir dan berargumentasi, memberikan konstribusi dalam penyelesian masalah sehari-hari dan dalam dunia kerja, serta memberikan dukungan dalam pengembangan ilmu pengetahuan dan tegnologi”.

Ilmu matematika juga banyak dimanfaatkan manusia untuk memodelkan fenomena-fenomena yang terjadi disekitarnya. Fenomena yang terjadi bisa dibuat dalam bentuk sifat matematis agar mudah dipecahkan. Sejalan dengan pendapat (Harefa, 2020), bahwa "fenomena yang berbeda dapat memperlihatkan sifat-sifat matematis yang identik. Sifat-sifat yang dimaksud itupun dapat dilambangkan ke dalam bilangan dan dalam keterhubungan angka-angka". Karena itu matematika sangat diperlukan dalam kehidupan sehari-hari, dan perlu dibekalkan pada setiap peserta didik sejak SD, bahkan sejak TK untuk mengahadapi kemajuan IPTEK. Menurut (Susanto, 2013) "matematika merupakan salah satu displin ilmu yang dapat meningkatkan kemampuan berpikir dan berargumentasi, memberikan konstribusi dalam penyelesian masalah sehari-hari dan dalam dunia kerja, serta memberikan dukungan dalam pengembangan ilmu pengetahuan dan tegnologi". Juga (Suherman, 2003) mengatakan bahwa "matematika adalah telaah 
tentang pola dan hubungan, suatu jalan atau pola berpikir, suatu seni, suatu bahasa, dan suatu alat".

Matematika merupakan salah satu bidang studi yang ada pada semua jenjang pendidikan, mulai dari tingkat sekolah dasar hingga perguruan tinggi. (Harefa, 2020) mengatakan bahwa "belajar matematika merupakan suatu syarat cukup untuk melanjutkan pendidikan kejenjang berikutnya". Sehingga, berdasarkan pendapat yang telah diuraikan di atas, maka peneliti menyimpulkan bahwa belajar matematika adalah displin ilmu yang dapat mengembangkan logika, cara berpikir, bernalar, dan berargumentasi serta memberikan konstribusi dalam penyelesaian masalah dalam kehidupan sehari-hari, dan juga memberikan dukungan dalam pengembangan ilmu pengetahuan dan teknologi. Mengingat pentingnya matematika, maka di dalam kurikulum pendidikan nasional, matematika merupakan salah satu mata pelajaran yang wajib diberikan kepada peserta didik. Dalam mempelajari matematikapun, peserta didik tidak hanya dituntut memahami materi yang diajarkan, tetapi juga diharapkan memiliki kemampuan matematis yang berguna untuk menghadapi tantangan global. Berdasarkan jenis kemampuan matematik dapat diklarifikasikan dalam lima kompetensi utama (Hendriana, H., Soemarmo, 2016) yaitu: 1) Pemahaman matematik (mathematical understanding); 2) Pemecahan masalah (mathematical problem solving); 3) Komunikasi matematik (mathematical comunication); 4) Koneksi matematik (mathematical connection); 5) Penalaran matematik (mathematical reasoning).

Diantara kemampuan-kemampuan matematis tersebut, kemampuan pemecahan masalah dan komunikasi matematis sangat diperlukan oleh setiap peserta didik dalam menghadapi tantangan pada era globalisasi dan informasi saat ini. Kedua kemampuan ini juga dinyatakan secara tertulis di dalam tujuan mata pelajaran matematika pada pendidikan dasar dan menengah yang tercantum di dalam KTSP (2006) yang disempurnakan pada kurikulum 2013 (Hendriana, 2018), sebagai berikut: 1) Memahami konsep matematika, menjelaskan keterkaitan antar konsep dan mengaplikasikan konsep atau logaritma, secara luwes, akurat, efesien, dan tepat dalam pemecahan masalah. 2) Menggunakan penalaran pada pola dan sifat, melakukan manipulasi matematika dalam membuat generalisasi, menyusun bukti, atau menjelaskan gagasan dan pernyataan matemtika. 3) Memecahkan masalah yang meliputi kemampuan memahami masalah, merancang model matematika, menyelesaikan model dan menafsirkan solusi yang diperoleh. 4) Mengomunikasikan gagasan dengan simbol, tabel, diagram, atau media untuk memperjelas keadaan atau masalah. 5) Memiliki sikap menghargai kegunaan matematika dalam kehidupan, yaitu memiliki rasa ingin tahu, perhatian, dan minat dalam mempelajari matematika, serta sikap ulet dan percaya diri dalam pemecahan masalah. Maka dapat disimpulkan bahwa kemampuan pemecahan masalah dan komunikasi matematis penting untuk dikembangkan dan dimiliki oleh setiap peserta didik melalui pembelajaran matematika di sekolah.

Pemecahan masalah merupakan bagian yang penting dalam pembelajaran matematika. Pemecahan masalah, dapat membangun sebuah percaya diri peserta didik dalam menyelesaikan masalah matematis. Selain itu, peserta didik yang memiliki kemampuan pemecahan masalah matematis, mampu meningkatkan pengambilan keputusan-keputusan dalam kehidupan sehari-hari. Sejalan dengan pendapat Cooney dalam (H. Laia, 2019) bahwa "pemilikan kemampuan pemecahan masalah membantu siswa berpikir analitik dalam mengambil keputusan dalam kehidupan sehari-hari dan 
membantu meningkatkan kemampuan berpikir kritis dalam menghadapi situasi baru". Masalah ialah sesuatu yang harus di selesaikan atau di pecahkan. Menurut (H. T. Laia, 2018) "masalah merupakan entitas yang sering dijadikan sebagai titik tolak dari seluruh kegiatan keilmuan yang akan dilakukan oleh seorang akademisi". Bell dalam Abidin (Armiati Armiati, 2020) memberikan definisi "masalah sebagai situasi yang dapat digolongkan sebagai masalah bagi seseorang adalah bahwa keadaan ini didasari, ada kemauan dan merasa perlu melakukan tindakan untuk mengatasinya dan melakukannya, serta tidak segera dapat ditemukan cara mengatasi situasi tersebut". Menurut (Abidin, 2015) "masalah adalah memberikan penjelasan yang belum jelas sehingga orang belum merasa puas dengan penjelasan tersebut". Stanic \& Kilpatrick dalam (Abidin, 2015) juga "mendefinisikan masalah sebagai suatu keadaan dimana seseorang melakukan tugasnya yang tidak ditemukan di waktu sebelumnya".

Peserta didik yang memiliki kemampuan pemecahan masalah matematis, dapat menyelesaikan masalah dengan langkah-langkah dan ketentuan matematika yang benar. Adapun langkah-langkah pemecahan masalah menurut Polya dalam (Abidin, 2015) antara lain: a) memahami masalah; b) merencanakan pemecahan masalah; c) melaksanakan rencana pemecahan masalah; d) melihat kembali hasil pemecahan masalah. Sehingga pada akhirnya dengan kemampuan pemecahan masalah matematis yang dimiliki peserta didik, teknik dalam penyelesaian masalahnya lebih terstruktur dan logis secara matematis. Selain kemampuan pemecahan masalah, kemampuan komunikasi dalam pembelajaran matematika juga penting untuk ditingkatkan. Pentingnya pemilikkan kemampuan komunikasi matematik dikemukakan oleh (Hendriana, 2018) dengan rasional: a) Matematika adalah bahasa esensial yang tidak hanya sebagai alat berpikir, menemukan rumus, menyelesaikan masalah, atau menyimpulkan saja, namun matematika juga memiliki nilai yang tak terbatas untuk menyatakan beragam idea secara jelas, teliti dan tepat. b) Matematika dan belajar matematika adalah jantungnya kegiatan sosial manusia, misalnya dalam pembelajaran matematika interaksi antara guru dan siswa, antara siswa dan siswa, antara bahan pembelajaran matematika dan siswa dalah faktor-faktor penting dalam memajukan potensi siswa.

Di dalam komunikasi matematika, para peserta didik memiliki kesempatan, dorongan, dukungan untuk berbicara, menulis, membaca dan mendengar suatu ekspresi matematika, serta mereka dapat berkomunikasi secara matematika karena matematika seringkali diberikan dalam komunikasi simbol, komunikasi tertulis, dan komunikasi lisan. Sejalan dengan pernyataan (Harefa, D., Telaumbanua, 2020) yang mengemukakan bahwa "Berkomunikasi secara matematika sering diberikan dalam komunikasi simbol, komunikasi tertulis, dan komunikasi lisan yang berisi gagasan matematika....". Sehingga dengan kemampuan komunikasi matematis yang dimiliki peserta didik lewat pembelajaran matematik, mempermudah bagi peserta didik dalam menyelesaikan masalah.

Kedua kemampuan matematis yang telah diuraikan di atas sangat berpengaruh pada pemecahan soal-soal matematis. Dan juga berpengaruh dalam memecahkan masalah-masalah dalam kehidupan sehari-hari yang berhubungan dengan hitung menghitung atau yang berkaitan dengan urusan angka-angka berbagai macam masalah, yang memerlukan suatu keterampilan dan kemampuan untuk memecahkan masalah. Menurut (Hendriana, H. \& Soemarmo, 2016) bahwa kemampuan komunikasi 
matematika dapat membantu menghasilkan model matematika yang diperlukan dalam pemecahan masalah baik dalam berbagai ilmu pengetahuan maupun dalam kehidupan sehari-hari. Artinya, jika seorang peserta didik tidak mampu mengkomunikasikan gagasan/ide dalam bentuk ekspresi matematika untuk memperjelas suatu masalah, maka akan menyulitkan peserta didik tersebut untuk memecahkan masalah.

Sejalan dengan hasil penelitian (Selvia, 2017) dengan judul korelasi kemampuan komunikasi matematik dengan kemampuan pemecahan masalah matematik terhadap peserta didik melalui model pembelajaran login avenue problem solving (LAPS)heuristic menyimpulkan bahwa Tanpa kemampuan komunikasi matematik yang dimiliki peserta didik akan sulit untuk memecahkan masalah matematik. Bahkan hasil penelitian (Ariawan, 207 C.E.) tentang hubungan kemampuan pemecahan masalah matematis dengan kemampuan komunikasi matematis siswa, menyimpulkan bahwa Semakin tinggi kemampuan pemecahan masalah matematis, maka semakin tinggi pula kemampuan komunikasi siswa. Oleh karena itu, peneliti menarik kesimpulan bahwa perlu diteliti lebih dalam bagaimana eratnya hubungan kemampuan pemecahan masalah matematis dengan kemampuan komunikasi matematis siswa kelas VII di SMP Negeri 2 Telukdalam.

\section{Metode}

Penulisan penelitian ini adalah penelitian kuantitatif dengan metode penelitian korelasional. Menurut (Arikunto, 2013) "penelitian korelasi adalah penelitian yang bertujuan untuk menemukan ada tidaknya hubungan dan apa bila ada, berapa eratnya hubungan serta berarti atau tidak hubungan itu". Sehingga penelitian ini berguna untuk mengetahui hubungan kemampuan pemecahan masalah dengan kemampuan komunikasi penelitian, tanpa melakukan perlakuan terlebih dahulu. Desain dalam penelitian ini adalah seperti pada gambar di bawah ini:

\section{Gambar 1. Desain Penelitian}

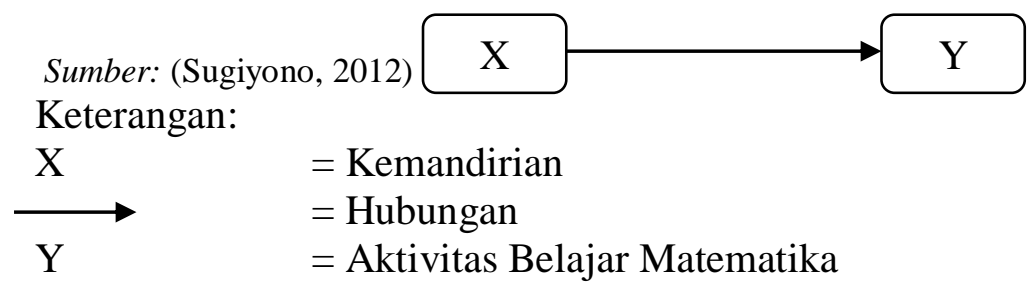

\section{Hasil dan Pembahasan \\ Hasil}

Setelah semua data terkumpul, langkah selanjutnya yang dilakukan adalah menganalisa data tersebut. Pengolahan data dilakukan secara manual dengan menggunakan microsoft exel tanpa bantuan software statistik tertentu. Analisis data dilakukan dengan uji prasyarat regresi linier, uji koefisien korelasi, uji signifikansi koefisien korelasi, dan koefisien korelasi. Berikut anlisis data yang telah terkumpul:

Adapun hasil tes kemampuan pemecahan masalah matematis (X) dan kemampuan komunikasi matematis siswa (Y) setelah melakukan pengumpulan data sebagai berikut: Kemampuan pemecahan masalah matematis siswa. Berdasarkan hasil tes kemampuan pemecahan masalah matematis siswa, di peroleh sebaran kemampuan sebagai berikut: 
Tabel 1. Distribusi dan Frekuensi Kemampuan Pemecahan Masalah Matematis Siswa (X)

\begin{tabular}{|c|c|c|c|}
\hline KATEGORI & INTERVAL SKOR & FREKUENSI & PERSENTASE \% \\
\hline Sangat Baik & $81-100$ & 0 & $0 \%$ \\
\hline Baik & $61-80$ & 7 & $10,45 \%$ \\
\hline Cukup Baik & $41-60$ & 59 & $88,06 \%$ \\
\hline Rendah & $21-40$ & 1 & $1,49 \%$ \\
\hline Sangat Rendah & $0-20$ & 0 & $0 \%$ \\
\hline \multicolumn{2}{|c|}{ Jumlah } & 67 & $100 \%$ \\
\hline
\end{tabular}

Keterangan:

Untuk frekuensi 7 yaitu: $\frac{7}{67} \times 100 \%=10,45 \%$, Untuk frekuensi 59 yaitu: $\frac{59}{67} \times 100 \%=88,06 \%$, Untuk frekuensi 1 yaitu: $\frac{1}{67} \times 100 \%=1,49 \%$

Berdasarkan Tabel 1 dapat dijelaskan keadaan kemampuan pemecahan masalah matematis siswa dengan kategori sangat baik $0 \%$, baik $10,45 \%$, cukup baik $88,06 \%$, rendah $1,49 \%$ dan sangat rendah $0 \%$. Selanjutnya berdasarkan hasil dari tes kemampuan pemecahan masalah matematis siswa, dapat dihitung rata-rata nilai sebagai berikut:

$$
\sum x_{i}=3452 ; n=67, \bar{X}=\frac{\sum x i}{\mathrm{~N}}=\frac{3452}{67}=51,5
$$

Berdasarkan perhitungan data hasil tes kemampuan pemecahan masalah matematis siswa diatas diperoleh rata-rata nilai akhir sebesar 51,5. Adapun perolehan rata-rata nilai akhir tersebut tergolong pada kategori Cukup Baik (Harefa, D., 2020).

Kemampuan komunikasi matematis siswa. Berdasarkan hasil tes kemampuan komunikasi matematis siswa, di peroleh sebaran kemampuan sebagai berikut :

Tabel 2. Distribusi dan Frekuensi Kemampuan Komunikasi Matematis Siswa (Y)

\begin{tabular}{|c|c|c|c|}
\hline KATEGORI & INTERVAL SKOR & FREKUENSI & PERSENTASE \% \\
\hline Sangat Baik & $81-100$ & 26 & $38,81 \%$ \\
\hline Baik & $61-80$ & 39 & $58,21 \%$ \\
\hline Cukup Baik & $41-60$ & 2 & $2,98 \%$ \\
\hline Rendah & $21-40$ & 0 & $0 \%$ \\
\hline Sangat Rendah & $0-20$ & 0 & $0 \%$ \\
\hline \multicolumn{2}{|c|}{ Jumlah } & 67 & $100 \%$ \\
\hline
\end{tabular}

Keterangan:

Untuk frekuensi 26 yaitu: $\frac{26}{67} \times 100 \%=38,81 \%$, Untuk frekuensi 39 yaitu: $\frac{39}{67} \times 100 \%=58,21 \%$, Untuk frekuensi 2 yaitu: $\frac{2}{67} \times 100 \%=2,98 \%$

Berdasarkan Tabel 4.3 dapat dijelaskan keadaan kemampuan komunikasi siswa dengan kategori sangat baik $38,81 \%$, baik $58,21 \%$, cukup baik $2,98 \%$, rendah $0 \%$ dan sangat rendah $0 \%$. Selanjutnya berdasarkan hasil dari tes kemampuan komunikasi matematis siswa, dapat dihitung rata-rata nilai sebagai berikut:

$$
\sum x_{i}=5194,1 ; n=67, \bar{X}=\frac{\sum x i}{\mathrm{~N}}=\frac{5194,1}{67}=77,5
$$

Berdasarkan perhitungan data hasil tes kemampuan komunikasi matematis siswa diatas diperoleh rata-rata nilai akhir sebesar 77,5. Adapun perolehan rata-rata nilai akhir tersebut tergolong pada kategori Baik. 
Uji Prasyarat Regresi Linier. Berdasarkan hasil olahan data tes kemampuan pemecahan masalah matematis siswa dan tes kemampuan komunikasi matematis siswa, dengan melihat persamaan regresi linier (Surur, M., 2020).

Tabel. 3 Rangkuman Data Nilai Persamaan Regresi Lienar

\begin{tabular}{cl}
\hline $\mathrm{N}=67$ & $\sum \mathrm{X}^{2}=181120$ \\
\hline$\sum \mathrm{X}=3452$ & $\sum \mathrm{Y}^{2}=406262,9$ \\
\hline$\sum \mathrm{Y}=5194,1$ & $\sum \mathrm{XY}=268988,2$
\end{tabular}

Formula regresi linier : $\mathbf{Y}^{\prime}=\mathbf{a}+\mathbf{b X}$

Hitung terlebih dahulu nilai konstanta (atau nilai a) sebagai berikut:

$$
\begin{aligned}
& \mathrm{a}=\frac{\left(\sum \mathrm{Y}\right)\left(\sum \mathrm{X}^{2}\right)-\left(\sum \mathrm{X}\right)\left(\sum \mathrm{XY}\right)}{\mathrm{n} \sum \mathrm{X}^{2}-\left(\sum \mathrm{X}\right)^{2}}=\frac{(5194,1)(181120)-(3452)(268988,2)}{(67)(181120)-(3452)^{2}} \\
& \mathrm{a}=\frac{12208125,6}{218736}=55,8
\end{aligned}
$$

Selanjutnya hitung nilai koefisien $\mathrm{x}$ (atau nilai $\mathrm{b}$ ), sebagai berikut:

$$
\begin{aligned}
& \mathrm{b}=\frac{\mathrm{n} \sum \mathrm{XY}-\left(\sum \mathrm{X}\right)\left(\sum \mathrm{Y}\right)}{\mathrm{n} \sum \mathrm{X}^{2}-\left(\sum \mathrm{X}\right)^{2}}=\frac{(67)(268988,2)-(3452)(5194,1)}{(67)(181120)-(3452)^{2}} \\
& \mathrm{~b}=\frac{92176,2}{218736}=0,42
\end{aligned}
$$

Berdasarkan data di atas didapat $a=55,8$ dan $b=0,42$ maka persamaan regresi liniernya yang terbentuk adalah $\mathrm{Y}^{s}=55,8+0,42 \mathrm{X}$. Terlihat bahwa niai $\mathrm{b}$ bernilai positif, artinya peningkatan yang terjadi adalah berbanding lurus. Semakin tinggi nilai $X$ (kemampuan pemecahan masalah matematis), maka akan semakin tinggi nilai $\mathrm{Y}$ (kemampuan komunikasi matematis) (Harefa, 2020).

Uji Kofisien Korelasi. Untuk mengetahui hubungan kedua variabel, maka digunakan rumus korelasi produk moment. Berikut analisis koefisien korelasi berdasarkan data yang telah diperoleh:

$$
\begin{aligned}
& r_{x y}=\frac{N \sum X Y-\left(\sum X\right)\left(\sum Y\right)}{\sqrt{\left\{N \sum X^{2}-\left(\sum X\right)^{2}\right\}\left(N \sum Y^{2}-\left(\sum Y\right)^{2}\right\}}} \\
& r_{x y}=\frac{(67)(268988,2)-(3452)(5194,1)}{\sqrt{\left.\left\{(67)(181120)-(3452)^{2}\right\}(67)(406262,9)-(5194,1)^{2}\right\}}} \\
& r_{x y}=\frac{92176,2}{\sqrt{(218736)(240939,49)}}=\frac{92176,2}{\sqrt{52702140284,64}} \\
& r_{x y}=\frac{92176,2}{229569,47}=0,40
\end{aligned}
$$

Berdasarkan perhitungan uji korelasi di atas didapat $r_{\text {hitung }}=0,40$. Dilihat dari kriteria interpretasi koefisien korelasi maka hubungan yang terjadi antara kedua variabel bersifat positif dan tergolong sedang.

Uji Signifikansi Koefisien Korelasi. Setelah melihat hubungan kedua variabel, maka perlu diuji signifikansi hubungan kedua variabel. Untuk menguji signifikansi hubungan, dengan menggunakan rumus signifikansi korelasi product moment. Berikut perhitungan uji signifikansi hubungan dengan menggunakan rumus signifikansi korelasi product moment : 


$$
\begin{aligned}
& t=\frac{r \sqrt{n-2}}{\sqrt{1-r^{2}}}=\frac{(0,40) \sqrt{(67)-2}}{\sqrt{1-(0,40)^{2}}}=\frac{(0,40) \sqrt{65}}{\sqrt{1-0,16}} \\
& t=\frac{(0,40)(8,06)}{(0,92)}=\frac{3,224}{0,92}=3,5043
\end{aligned}
$$

Berdasarkan perhitungan di atas didapat uji signifikansi sebesar $t_{\text {hitung }}=3,5043$ dan selanjutnya pada nilai tabel dengan taraf nyata $0,05(5 \%)$ dengan $\mathrm{dk}=\mathrm{n}-2$ di peroleh nilai $\mathrm{dk}=65$ maka nilai $\mathrm{t}_{\text {tabel }}=1,9971$. Karena $\mathrm{t}$ hitung lebih besar dari $\mathrm{t}$ tabel ( thitung $>t_{\text {tabel }}$ ), maka $\mathrm{H}_{\mathrm{a}}$ diterima dan $\mathrm{H}_{\mathrm{o}}$ di tolak. Artinya, ada hubungan kemampuan pemecahan masalah matematis dengan kemampuan komunikasi matematis siswa.

Koefisien Determinasi. Setelah melakukan uji signifikansi hubungan kedua variabel, Selanjutnya menghitung presentase kontribusi kedua variabel. Perhitungannya sebagai berikut:

$$
\mathrm{KD}=\mathrm{r}^{2} \times 100 \%=(0,40)^{2} \times 100 \%=16,11 \%
$$

Berdasarkan hasil koefisien determinasi diatas menunjukkan bahwa kontribusi kemampuan pemecahan masalah matematis terhadap kemampuan komunikasi matematis sebesar $16,11 \%$ dan selebihnya merupakan kontribusi dari faktor lain.

\section{Pembahasan}

Setelah data terambil dan diolah, maka adapun hasil tes kemampuan pemecahan masalah matematis siswa kelas VII di SMP Negeri 2 Telukdalam, data menunjukkan $10,45 \%$ siswa berkemampuan baik, $88,06 \%$ siswa berkemampuan cukup baik, dan $1,49 \%$ siswa berkemampuan rendah. Namun, nilai rata-rata kemampuan pemecahan masalah matematis siswa secara keseluruhan tergolong pada kategori cukup baik, yaitu dengan nilai rata-rata 51,5. Sedangkan pada hasil tes kemampuan komunikasi matematis siswa menunjukkan $38,81 \%$ siswa berkemampuan sangat baik, $58,21 \%$ siswa berkemampuan baik, dan 2,98\% siswa berkemampuan cukup baik. Namun, nilai ratarata kemampuan komunikasi matematis siswa secara keseluruhan tergolong pada kategori baik, yaitu dengan nilai rata-rata 77,5.

Berdasarkan hasil uji $\mathrm{t}$ terlihat bahwa $\mathrm{t}_{\text {hitung }}>\mathrm{t}_{\text {tabel }}$ dimana $\mathrm{t}_{\text {hitung }}=3,5043$ sedangkan $\mathrm{t}_{\text {tabel }}=1,9971$, hal ini menunjukkan bahwa adanya hubungan yang signifikan antara kemampuan pemecahan masalah matematis dengan kemampuan komunikasi matematis siswa. Dilihat dari uji koefisien korelasi $\mathrm{r}_{\mathrm{xy}}=0,40$ pada taraf signifikan 0,05, menunjukkan bahwa hubungan kedua variabel memiliki hubungan yang positif dan sedang. Sedangkan, hasil uji regresi linier dimana $\mathrm{Y}^{p}=55,8+0,42 \mathrm{X}$, menunjukkan bahwa nilai $b$ bernilai positif, artinya peningkatan yang terjadi adalah berbanding lurus. Semakin tinggi nilai $\mathrm{X}$ (kemampuan pemecahan masalah matematis) maka akan semakin tinggi nilai $\mathrm{Y}$ (kemampuan komunikasi matematis).

Hal ini relevan dengan penelitian yang dilakukan oleh (Ariawan, 207 C.E.) yang berjudul hubungan kemampuan pemecahan masalah matematis dengan kemampuan komunikasi matematis siswa di SMP Negeri 25 Pekan Baru Tahun Ajaran 2013/2014, dimana $t_{\text {hitung }}=4,084$ dan $t_{\text {tabel }}=1,980$, menunjukkan bahwa ada hubungan kemampuan pemecahan masalah matematis dengan kemampuan komunikasi matematis siswa, sedangkan $r_{x y}=0,32$, menunjukkan hubungan kedua variabel memiliki hubungan yang positif dan lemah. Adapun penelitian ini, menunjukkan terdapat hubungan yang signifikan antara kemampuan pemecahan masalah matematis dengan kemampuan 
komunikasi matematis siswa. Artinya, semakin tinggi kemampuan pemecahan masalah matematis maka akan semakin tinggi pula kemampuan komunikasi siswa tersebut.

Ini artinya kemampuan pemecahan masalah matematis dan kemampuan komunikasi matematis merupakan dua kemampuan yang tidak dapat dipisahkan dalam pembelajaran matematika maupun dalam kehidupan sehari-hari. Sejalan pendapat (Hendriana, H. \& Soemarmo, 2016) bahwa "kemampuan komunikasi matematika dapat membantu menghasilkan model matematika yang diperlukan dalam pemecahan masalah baik dalam berbagai ilmu pengetahuan maupun dalam kehidupan sehari-hari”.

Adapun koefisien determinasi yang di dapat dalam penelitian ini sebesar $16,11 \%$. Hal tersebut, mengungkapkan bahwa besarnya sumbangan kemampuan pemecahan masalah matematis terhadap kemampuan komunikasi matematis siswa sebesar 16,11\%. Sedangkan 83,89\% merupakan sumbangan dari faktor lain.

Maka dari uraian data di atas dapat disimpulkan bahwa terdapat hubungan antara kemampuan pemecahan masalah matematis dengan kemampuan komunikasi matematis siswa. Hubungan yang terjadi bersifat positif dan cenderung kuat. Dimana, semakin tinggi kemampuan pemecahan masalah matematis maka akan semakin tinggi kemampuan komunikasi matematis siswa. Sedangkan, berdasarkan koefisien determinasi, terlihat jelas bahwa tinggi rendahnya kemampuan komunikasi matematis peserta didik lebih dipengaruhi oleh faktor lain dibandingkan kemampuan pemecahan masalah matematis mereka.

\section{Simpulan}

Berdasarkan hasil pengolahan data penelitian dan pembahasan hasil penelitian yang telah diuraikan, maka dapat disimpulkan bahwa Terdapat hubungan yang positif dan signifikan antara kemampuan pemecahan masalah matematis dengan kemampuan komunikasi matematis siswa kelas VII di SMP Negeri 2 Telukdalam tahun pembelajaran 2020/2021 dengan $r_{x y}=0,40$ karena kemampuan komunikasi matematika dapat membantu menghasilkan model matematika yang diperlukan dalam pemecahan masalah baik dalam berbagai ilmu pengetahuan maupun dalam kehidupan sehari-hari. Kemampuan pemecahan masalah matematis siswa kelas VII di SMP Negeri 2 Telukdalam tahun pembelajaran 2020/2021 berdasarkan kriteria klarifikasi presentase data menunjukkan 10,45\% siswa berkemampuan baik, 88,06\% siswa berkemampuan cukup baik, dan $1,49 \%$ siswa berkemampuan rendah. Sedangkan, nilai rata-rata kemampuan pemecahan masalah matematis siswa secara keseluruhan tergolong pada kategori cukup baik, yaitu dengan nilai rata-rata 51,5. Kemampuan komunikasi matematis siswa kelas VII di SMP Negeri 2 Telukdalam tahun pembelajaran 2020/2021 berdasarkan kriteria klarifikasi presentase data menunjukkan 38,81\% siswa berkemampuan sangat baik, 58,21\% siswa berkemampuan baik, dan 2,98\% siswa berkemampuan cukup baik. Sedangkan, nilai rata-rata kemampuan komunikasi matematis siswa secara keseluruhan tergolong pada kategori baik, yaitu dengan nilai rata-rata 77,5

\section{Daftar Pustaka}

Abidin, Z. (2015). Intuisi Dalam Pembelajaran Matematika. Lentera Ilmu Cendekia.

Ariawan, R. (207 C.E.). Hubungan Kemampuan Pemacahan Masalah Matematis dengan Kemampuan Komunikasi Siswa. The Original Research of Mathematics, 1(2). 
AKSARA: Jurnal Ilmu Pendidikan Nonformal

P-ISSN $\underline{2407-8018}$ E-ISSN $\underline{2721-7310}$ DOI prefix $\underline{10.37905}$

Volume 07 (02) Mei 2021

http://ejurnal.pps.ungac.id/index.php/Aksara

Arikunto, S. (2013). Dasar-dasar Evaluasi Pendidikan. Bumi Aksara.

Armiati Armiati, H. T. (2020). Dampak Perangkat Pembelajaran Matematika Berbasis

Kompetensi Profesi Terhadap Kemampuan Pemecahan Masalah Siswa Bidang

Keahlian Teknologi Informasi dan Komunikasi. JURNAL EKSAKTA

PENDIDIKAN (JEP), 4(1), 57-65.

Dimyati dan Mudjiono. (2009). Belajar Dan Pembelajaran. PT. Rineka Cipta.

Harefa, D., Telambanua, K. (2020). Teori manajemen bimbingan dan konseling. CV. Embrio Publisher.

Harefa, D., Telaumbanua, T. (2020). Belajar Berpikir dan Bertindak Secara Praktis Dalam Dunia Pendidikan kajian untuk Akademis. CV. Insan Cendekia Mandiri.

Harefa, D., D. (2020). Penerapan Model Pembelajaran Cooperatifve Script Untuk Meningkatkan Hasil Belajar Matematika. JKPM (Jurnal Kajian Pendidikan Matematika), 6(1), 13-26.

Harefa, D., D. (2020). Teori Model Pembelajaran Bahasa Inggris dalam Sains. CV. Insan Cendekia Mandiri.

Harefa, D. (2020). Belajar Fisika Dasar Untuk Guru, Mahasiswa dan Pelajar. CV. Mitra Cendekia Media.

Harefa, D. (2020). Pengaruh Antara Motivasi Kerja Guru IPA dan Displin Terhadap Prestasi Kerja. Aksara: Jurnal Ilmu Pendidikan Nonformal, 6(3), 225-240.

Harefa, D. (2020). Perkembangan Belajar Sains Dalam Model Pembelajaran. CV. Kekata Group.

Harefa, D. (2020) . Teori Ilmu Kealaman Dasar Kajian Untuk Mahasiswa Pendidikan Guru dan Akademis. Penerbit Deepublish. Cv Budi Utama.

Harefa D., dkk. (2020). Peningkatan Hasil Belajar IPA pada Model Pembelajaran Creative Problem Solving (CPS). Musamus Journal of Primary Education, 3(1), 118.

Harefa. D, dkk (2020). Peningkatan Hasil Belajar Melalui Model Problem Based Learning Terintergrasi Brainstorming Berbasis Modul Matematika SMP. Histogram : Jurnal Pendidikan Matematika (4) (2).

Harefa, D., dkk. (2021). Pemanfaatan Laboratorium IPA Di SMA Negeri 1 Lahusa. EduMatSains: Jurnal Pendidikan, Matematika dan Sains. 5 (2) 105-122

Harefa, D., Dkk. (2021). Peningkatan Hasil Belajar Siswa Pada Model Pembelajaran Index Card Match Di SMP Negeri 3 Maniamolo. Jurnal Ilmiah Aquinas, 4 (1) 1-14

Hendriana, H. \& Soemarmo, U. (2016). Penilaian Pembelajaran Matematika. PT Refika Aditama.

Hendriana, H., Soemarmo, U. (2016). Penilaian Pembelajaran Matematika. PT. Refika Aditama.

Hendriana, R. dan S. (2018). Hard Skill dan Soft Skill Matematik Siswa. PT. Refika Aditama.

Laia, H. (2019). Hubungan Motivasi Berprestasi Terhadap Hasil Belajar Matematika Pada Materi Pokok Operasi Hitung Bentuk Aljabar Terhadap Siswakelas VII SMP Negeri 1 Telukdalam Tahun Pembelajaran 2018/2019. Jurnal Education and Development Institut Pendidikan Tapanuli Selatan, 7(4).

Laia, H. T. (2018). The Developed Mathematics Learning Tools Which Based on Professional Competency In The Phase of One to One Evaluation For Trigonometry Topic In The Major of Information and Communication Engineering 
of SMK. Atlantis Press.

Selvia. (2017). Korelasi Kemampuan Komunikasi Matematik dengan Kemampuan Pemecahan Masalah Matematik terhadap Peserta Didik Melalui Model Pembelajaran Logan Avenue Problem Solving (LAPS)-Heuristic. Jurnal Penelitian Pendidikan Dan Pengajaran Matematika, 3(2).

Slameto. (2010). Belajar dan Faktor-Faktor Yang Mempengaruhi. Rineka Cipta.

Sugiyono. (2012). Metode Penelitian Kuantitatif Kualitatif dan R\&D. Bandung. Alfabeta.

Suherman, E. dkk. (2003). Strategi Pembelajaran Matematika Kontemporer. JICA Universitas Pendidikan Indonesia.

Surur, M., D. (2020). Effect Of Education Operational Cost On The Education Quality With The School Productivity As Moderating Variable. Psychology and Education Journal, 57(9), 1196-1205.

Susanto. (2015). Pemahaman Pemecahan Masalah Berdasar Gaya Kognitif. Deepublish.

Susanto, A. (2013). Teori Belajar \& Pembelajaran di Sekolah Dasar. Kencana Prenadamedia Group.

Telaumbanua, M., Harefa, D. (2020). Teori Etika Bisnis dan Profesi Kajian bagi Mahasiswa \& Guru. Yayasan Pendidikan dan Sosial Indonesia Maju (YPSIM) Banten. 
AKSARA: Jurnal Ilmu Pendidikan Nonformal

P-ISSN 2407-8018 E-ISSN 2721-7310 DOI prefix $\underline{10.37905}$

Volume 07 (02) Mei 2021

http://ejurnal.pps.ungac.id/index.php/Aksara

474 AKSARA: Jurnal IImu Pendidikan Nonformal 